\title{
High maternal haemoglobin and its relation to pregnancy induced hypertension
}

\author{
Manjunatha S. ${ }^{*}$, Amruta S. Bennal ${ }^{2}$ \\ ${ }^{1}$ Department of Obstetrics and Gynecology, Kodagu institute of medical sciences, Madikeri, Karnataka, India
}

${ }^{2}$ Navodaya medical college, Raichur, Karnataka, India

Received: 01 November 2015

Accepted: 19 November 2015

*Correspondence:

Dr. Manjunatha S.,

E-mail: hsogmanju@gmail.com

Copyright: $(\odot$ the author(s), publisher and licensee Medip Academy. This is an open-access article distributed under the terms of the Creative Commons Attribution Non-Commercial License, which permits unrestricted non-commercial use, distribution, and reproduction in any medium, provided the original work is properly cited.

\begin{abstract}
Background: Pregnancy induced hypertension $(\mathrm{PIH})$ is poorly understood condition of human pregnancy. It is a pregnancy specific disorder that can affect virtually every organ system. Exact cause is not known, thought to be multifactorial. The underlying pathology is endothelial dysfunction and intensive vasospasm, affecting almost all vessels. The responsible agent for dysfunction and vasospasm, still not been isolated precisely. So we have done the study to know the association of first trimester, high maternal haemoglobin with occurrence of PIH.

Methods: The longitudinal study was conducted in the 400 pregnant women, who were enrolled in first trimester of pregnancy and followed till the delivery, with 200 pregnant women with haemoglobin $>13 \mathrm{gm} \%$ as cases and 200 pregnant women haemoglobin 11 to $13 \mathrm{gm} \%$ as controls. Statistical analysis was done by using Chi-square test.

Results: The pregnant women with higher haemoglobin concentration in first trimester had higher risk of developing pre-eclampsia (PIH) comparing to other pregnant women ( $\mathrm{p}<0.0001)$.

Conclusions: High haemoglobin concentration in first trimester of pregnancy can be considered as risk factor Pregnancy induced hypertension.
\end{abstract}

Keywords: PIH, Maternal haemoglobin, Pregnant women, Hypertension

\section{INTRODUCTION}

Quality of life for mother and newborn has become our most important concern now a days. Pregnancy induced hypertension is defined as the hypertension that develop is a multisystem disorder of unknown etiology charecterised by development of hypertension to the extent of $140 / 90 \mathrm{~mm} \mathrm{Hg}$ or more with protinuria after the 20th week in previously normotensive and nonproteinuric patients. ${ }^{1}$ It is poorly understood condition of human pregnancy, which can affect multiple organs and is leading cause of maternal mortality worldwide. ${ }^{2} \mathrm{PIH}$ more often affects nulliparous women. ${ }^{3}$ Pre-eclampsia is the most frequently encountered medical complication during pregnancy 4 with, overall worldwide incidence of Pre-eclampsia is $3-5 \%,{ }^{5}$ but in India, overall incidence is 5-15\%. ${ }^{1}$ Although the etiology of preeclampsia remains unknown, it is suggested that preeclampsia is associated with intervillous and spiral artery thrombosis, vascular endothelial damage and abnormalities of coagulation, leading to inadequate maternal, fetal and placental circulation. ${ }^{6}$ Immunological adaptation disorders, abnormal increase of vasoconstrictor tone, nutritional factors, and genetic factors are some other theories. ${ }^{7}$ The underlying pathology is endothelial dysfunction and intensive vasospasm, affecting almost all vessels. The responsible agent for dysfunction and vasospasm, still not been isolated precisely. ${ }^{1}$ Routinely haemoglobin is assessed as a part of routine antenatal check-up. There are very few studies which have suggested that, high Hemoglobin concentration in first trimester of pregnancy is associated 
with occurrence of pre-eclampsia. ${ }^{8}$ Some studies have linked high maternal serum hemoglobin levels $(\mathrm{Hb}=13.2$ gm\%) in pregnancy outcomes, such as preeclampsia, preterm birth and small for gestational age. ${ }^{9}$ Many investigators believe that the conditions for the development of preeclampsia are set as early as the first trimester. ${ }^{10}$ Present study is done to know the relationship between high maternal haemoglobin and PIH .

\section{METHODS}

The study was conducted in Navodaya Medical College, Raichur. The study protocol was approved by the Institute's Ethical Committee and each subject signed an informed consent statement prior to participation and could withdraw without prejudice at any time. Age group 20 to 30 years and women attending OBG department for antenatal checkup are taken for the study. The study group consisted of 200 antenatal pregnant women in first trimester, with normal blood pressure and with hemoglobin more than $13 \mathrm{gm} \%$. The control group consists 200 antenatal pregnant women in first trimester, with normal blood pressure and with hemoglobin less than $13 \mathrm{gm} \%$ and above $11 \mathrm{~g} \mathrm{~m} \%$. Hemoglobin concentration was set to 13 gm\% as per this study. ${ }^{9}$ Previous history of hypertension, Diabetes Mellitus, renal disease, thyroid disorder, dyslipidemia, multiple pregnancy, previous history of pre-eclampsia, pregnant women with any other medication except for vitamins, Iron \& Calcium, were excluded from the study. Height and weight of the individuals were measured. BMI was calculated. The subjects and controls were advised to come for follow up every-month till delivery. Each visit the Blood Pressure was measured using sphygmomanometer. The subjects and controls were monitored till the delivery. The women with blood pressure more than Blood pressure $\geq 140 / 90 \mathrm{mmHg}$ after 20 weeks of gestation were considered pregnancy induced hypertension (PIH). ${ }^{11}$ Maintaining all aseptic precautions, $2 \mathrm{ml}$ of blood was drawn from ante-cubital vein and collected in an EDTA containing tube. The hematological investigations were performed on a fully automated Orphee Mythic - 18 three part differential cell counter.

\section{Statistical analysis}

After gathering the data, results were expressed in excel sheet and calculated for percentage. Both groups were compared regarding PIH and chi-square $\left(\chi^{2}\right)$ was applied and $\mathrm{p}$ value $<0.05$ was considered as significant.

\section{RESULTS}

The longitudinal study was conducted in the 400 pregnant women, who were enrolled in first trimester of pregnancy and followed till the delivery. There was no statistical significant difference in the age group and other anthropometric parameters when they were included in the study. Among them 200 pregnant women with haemoglobin more than $13 \mathrm{gm} \%$, were taken as study subjects and 200 pregnant women with haemoglobin more than 11 to $13 \mathrm{gm} \%$ were taken controls. In the study group 9 pregnant women developed pre-eclampsia and in control group 4 developed pre-eclampsia. Chi-square test showed statistically significant difference in two groups. The results were represented in table (Table 1) and graphs (Figure 1).

Table 1: PIH in normal $\mathrm{Hb}$ group and high level $\mathrm{Hb}$ group.

\begin{tabular}{|c|c|c|c|c|c|}
\hline & $\begin{array}{l}\text { Control } \\
(\%)\end{array}$ & $\begin{array}{l}\text { Study } \\
\text { group } \\
(\%)\end{array}$ & Total & $\begin{array}{l}\chi^{2} \\
\text { value }\end{array}$ & $\begin{array}{c}\text { p- } \\
\text { value }\end{array}$ \\
\hline $\begin{array}{l}\text { Developed } \\
\text { PIH }\end{array}$ & $\begin{array}{l}8 \\
(4)\end{array}$ & $\begin{array}{l}36 \\
(18)\end{array}$ & 44 & \multirow[t]{3}{*}{20.02} & \multirow[t]{2}{*}{$\mathrm{P}<0.0001$} \\
\hline No PIH & $\begin{array}{l}192 \\
(96)\end{array}$ & $\begin{array}{l}164 \\
(82)\end{array}$ & 356 & & \\
\hline Total & 200 & 200 & 400 & & \\
\hline
\end{tabular}

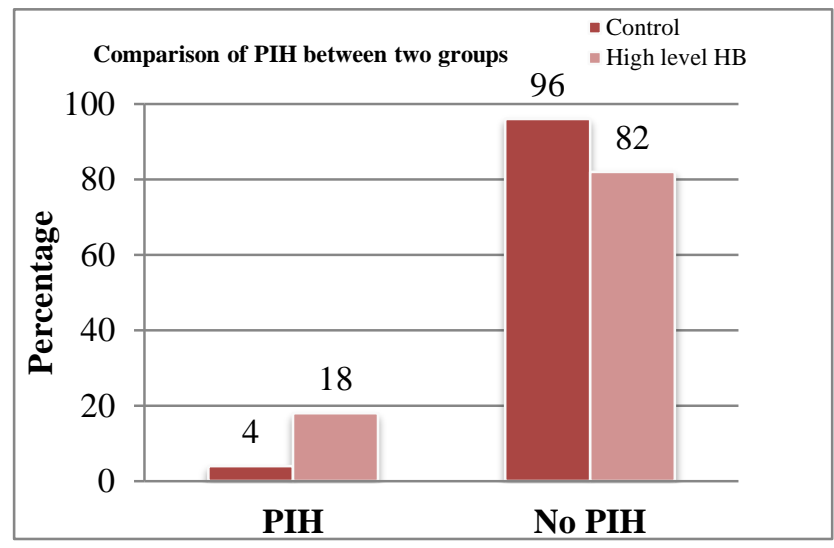

Figure 1: Comparison of PIH between two groups.

\section{DISCUSSION}

Our study indicates that women with high $\mathrm{Hb}$ concentration during the first trimester are associated with higher risk of developing PIH. Our findings show that there was a statistically significant relation between high maternal hemoglobin in the first trimester of pregnancy and preeclampsia. PIH might be explained by a generalized vasoconstriction and abnormal endothelial cell function ${ }^{11}$ Muphy et al showed that the levels of hemoglobin in the first and second trimesters were related to adverse pregnancy outcome such as preeclampsia. ${ }^{12}$ Sarrel et al suggested that an increased free hemoglobin concentration was the cause of vasoconstriction in preeclampsia. ${ }^{13}$ High hemoglobin concentration might affect growth is the development of preeclampsia (a syndrome of hypertension, proteinuria, and multiorgan dysfunction), which complicates $\approx 2 \%$ of all pregnancies. Failure of the plasma volume to expand is associated with a $\leq 3$-fold increase in the incidence of preeclampsia in pregnancy. Thus, the poor placental flow associated with not only high hemoglobin concentrations but also 
maternal vascular dysfunction might be implicated in fetal growth restriction. ${ }^{12}$ The principal mechanism for perinatal morbidity and mortality due to $\mathrm{PIH}$ is poor placental and fetal perfusion. The mechanism for the observed higher haemoglobin concentration is the failure of normal plasma expansion, hypovolemia and poor placental perfusion are all part of physiologic disturbance of PIH. ${ }^{14}$ In preeclampsia, the loss of serum protein and the increase in capillary endothelial permeability led to a decrease in intravascular volume and increased tissue edema. ${ }^{15}$ All organs could be affected, including the liver, brain, and the lungs. The decrease in blood volume could lead to an increase in maternal hemoglobin concentration. ${ }^{16}$ Many investigators believed that the conditions in the development of preeclampsia were set as early as the first trimester. ${ }^{10}$ Measuring the rate of haemoglobin in the first visit of pregnant women is performed in all cases in routine form. This method could be beneficial for recognizing mothers who were exposed to danger. $^{12}$

\section{CONCLUSIONS}

By considering present and previous studies that have been performed on this subject, high maternal haemoglobin is one of the risk factor for PIH; evaluating main risk factors like: type of nutrition, iron resources, medicine that causes haemoglobin to increase is necessary. Haemoglobin estimation has to be done during each antenatal check-up from first trimester till delivery.

Funding: No funding sources Conflict of interest: None declared

Ethical approval: The study was approved by the Institutional Ethics Committee

\section{REFERENCES}

1. Text book of Obstetrics. D.C. Dutta 6th edition 2004 D.C. Dutta, Text book of obstetrics, Hypertensive disorders in pregnancy. New Central Book Agency 6th Edition; 2004: 222.

2. Sibai BM. Hypertension in pregnancy. In: S.G. Gabbe, J R Niebyl, J. L. Simpson editors. Obst. Normal and problem of pregnancies. 3rd edition, New York: Churchill Livingstone. 1996: 935991.
3. Williams Obstetrics, Hypertensive disorders of pregnancy. Mc Graw-Hill, 21st Edition. 2001: 568.

4. Aziz R, Mahboob T. Pre-eclampsia and lipid profile. Pak J Med Sci. 2007:23(5);751-4.

5. Wang A, Rana S, Karumanchi SA. Preeclampsia: The Role of Angiogenic Factors in its Pathogenesis: Physiology: 2009:24;147-58.

6. Roberts JM, Cooper DW. Pathogenesis and genetics of preeclampsia. Lancet. 200;357:53-6.

7. Lopez-Jaramillo P, Casas JP, Serrano N. Preeclampsia: from epidemiology observation to molecular mechanisms. Brazil J Med Biol Res. 2001;34:1227-35.

8. Aghamohammadi A, Zafari M, Tofighi M. High maternal hemoglobin concentration in first trimester as risk factor for pregnancy induced hypertension. Caspian J Intern Med. 2011;2(1):194-197.

9. Tarim E, Kilicdag E, Bagis T, Ergin T. High maternal hemoglobin and ferritin values as risk factors forgestational diabetes. Int J Gynecol Obstet. 2004;84:259-61.

10. Vedernikov Y, Saade GR, Garfield RE. Vascular Reactivity in Preeclampsia. Lancet. 1999;23:34-4.

11. Williams OBSTETRICS, Hypertensive disorders of pregnancy. Mc Graw-Hill, 23rd Edition: 2010.

12. Murphy JF, O'Riordan J, Newcombe J, Coles EC, Pearson JF. Relation of haemoglobin levels in first and second trimesters to outcome of pregnancy. Lancet. 1986;1:992-5.

13. Sarrel PM, Lindsay DC, Poole-Wilson PA, Collins P. Hypothesis: inhibition of endothelium-derived relaxing factor by haemoglobin in the pathogenesis of pre-eclampsia. Lancet. 1990;336:1030-2.

14. Gunningham FG, Hypertensive disorders of pregnancy. In; Eastman NJ. Hellman LM, eds. William obstetrics.19th ed. Norwalk CT: Appleton and Lange. 1993:763-818.

15. Chappel LL, Bewley S. Pre-eclamptic toxaemia: the role of uterine artery Doppler. Br J Obstet Gynaecol. 1998;105:379-82.

16. Walker JJ. Pre-eclampsia. Lancet. 2000;356:1260-5.

Cite this article as: Manjunatha S, Amruta S B. High maternal haemoglobin and its relation to pregnancy induced hypertension. Int J Reprod Contracept Obstet Gynecol 2015;4:1746-8. 